\title{
Effect of bee pollen supplement on antimicrobial, chemical, rheological, sensorial properties and probiotic viability of fermented milk beverages
}

doi: 10.15567/mljekarstvo.2014.0406

Oktay Yerlikaya

Ege University Faculty of Agriculture Department of Dairy Technology, 35100 Bornova/İzmir, Turkey

Received - Prispjelo: 05.12.2013. Accepted - Prihvaćeno: 12.09.2014.

\begin{abstract}
In this research, effect of bee pollen supplement on antimicrobial, chemical, rheological, sensorial properties and probiotic viability of fermented milk beverages was studied. Bee pollens were added in the rate of $2.5 \mathrm{mg} \cdot \mathrm{mL}^{-1}$ (B), $5 \mathrm{mg} \cdot \mathrm{mL}^{-1}$ (C), $7.5 \mathrm{mg} \cdot \mathrm{mL}^{-1}$ (D), $10 \mathrm{mg} \cdot \mathrm{mL}^{-1}$ (E), and 20 $\mathrm{mg} \cdot \mathrm{mL}^{-1}(\mathrm{~F})$. Control sample (A) was not supplemented with bee pollen. Control and supplemented milk samples were fermented by a commercial ABT1 starter culture (Chr. Hansen, Hørsholm, Denmark) containing Lactobacillus acidophilus La 5, Bifidobacterium animalis subs. lactis $\mathrm{Bb} 12$, and Streptococcus thermophilus. While no antimicrobial impact was observed against L. monocytogenes, $S$. aureus, $P$. fluorescens, $P$. aeruginosa and A. hydrophilia upto $7.5 \mathrm{mg} \cdot \mathrm{mL}^{-1}$ pollen addition, addition between $10 \mathrm{mg} \cdot \mathrm{mL}^{-1}$ to $20 \mathrm{mg} \cdot \mathrm{mL}^{-1}$ resulted in activity, and positive effect only in inhibition rates against bacteria such as $S$. thyphimurium and E. coli. Bee pollen supplements has shown a positive effect on probiotic viability and occurred on increase apparent viscosity, but their effect on sensorial properties was negative. Furthermore an improvement with increasing concentration of pollen addition that yielded no negative effect on physicochemical properties was detected.
\end{abstract}

Key words: bee pollen, fermented milks, rheological properties, antimicrobial activity, sensorial properties

\section{Introduction}

Functional foods generally contain one or more beneficial compounds such as prebiotic, probiotic, antioxidant polyphenols and sterols, carotenoids, and others. These foods present a potential to promote health by maximizing physiological functions of a person and not for the cure of illnesses (Granato et al., 2010).

Fermented milks are widely produced in many countries. Fermentation is one of the oldest methods used to extend the shelf-life of milk, and has been practiced for thousands of years (Tamime, 2002). Numerous scientific papers and review articles have been published on the health benefits associated with the consumption of fermented dairy products
(Dave and Shah, 1998). Therefore, every year the food industry develops new fermented milk products that are required by consumers for their health benefits (Salva et al., 2011). Fermented milk beverages containing Lactobacillus acidophilus and Bifidobacterium spp. are well known dairy probiotic products produced in many countries as functional dairy products (Moayednia et al., 2009).

The majority of probiotic products available in the marketplace contain species of Lactobacillus and Bifidobacterium, which are the main genera of Grampositive bacteria currently characterized as probiotics (Granato et al., 2010; FAO/WHO, 2001). Different species of probiotic microorganisms have been employed in the food industry, such as: Lactobacillus acidophilus, Lactobacillus casei, Lactobacillus 
johnsonii, Lactobacillus rhamnosus, Lactobacillus thermophilus, Lactobacillus reuteri, Lactobacillus delbrueckii subsp. bulgaricus, Bifidobacterium bifidum, Bifidobacterium longum, Bifidobacterium brevis, Bifidobacterium infantis and Bifidobacterium animalis (Knorr, 1998). Lactobacillus delbrueckii subsp. bulgaricus, and Streptococcus thermophilus are found in a number of preparations such as traditional yoghurts, frozen yoghurts, and in desserts in some places (Granato et al., 2010; Senok, 2009). Interest for probiotics has arisen in recent years especially in relation to the addition of Bifidobacterium, Lactobacillus acidophilus, Lactobacillus rhamnosus, Lactobacillus casei, Lactobacillus reuteri to the fermented dairy products such as yoghurt (Guldas and Irkin, 2010). Yoghurts and fermented milks are still the main vehicles for incorporation of probiotic cultures. A probiotic dairy product should contain at least 6-7 Log cfu x g-1 of viable probiotic bacteria at the time of consumption and, should be consumed regularly in a quantity of higher than $100 \mathrm{~g}$ per day, or in other words at least 9 Log cfu per day (Kesenkas, 2010).

Some starter cultures such as ABT (ABT-1 and ABT-2) from Chr. Hansen, Hørsholm, Denmark may necessitate the incorporation of micronutrients (peptides and amino acids) for reducing the fermentation time and for improving the probiotic viability. The added ingredients considerably affected the incubation time, as some provided peptides and amino acids for bacterial growth (Dave and Shah, 1998; Tamime, 2005).

Bee pollen is a powder-like material produced by flowering plants pollen, mixed with nectar and bee secretions and gathered by the honey-bees. Pollens are the male reproductive cells of flowers and bees' primary food source, containing concentrations of phytochemicals and nutrients and rich in secondary metabolites. The old Egyptians describe pollen as "a life-giving dust." Pollen is called the only perfectly complete food and the main biological components of bee pollen are the phenolic acid derivatives and polyphenolic compounds, mostly flavonoid glycosides. The flavonoids are so called secondary plant compounds which have different important physiological and pharmacological activities. They possess diverse biological properties such as antioxidant, antiaging, anti-carcinogenic, antiinflammatory, anti-atherosclerosis, cardioprotective and improve the endothelial function (Graikou et al., 2011; Bogdanov, 2013).
Pollen is collected from flowers and one of the most important source of proteins, lipids, minerals and vitamins for bee survival. Recently, increasing evidence suggests its potential therapeutic benefits, including antioxidant properties and bioactive properties as functional dietary food supplement. In addition to saccharides, pollen contains $7.4 \%$ moisture, at least $20.0 \%$ proteins, $6.0 \%$ lipids and $2.2 \%$ ash, plus minerals, vitamins and carotenoids. Proline, aspartic acid, phenylalanine and glutamic acid are the primary amino acids in pollen (Roldán et al., 2011).

The phenolic composition of pollen principally consists of flavonol glycosides and hydroxycinnamic acids. It is popularly believed that regular consumption of bee pollen has a beneficial effect on several medical conditions, such as: depression, anemia, stress-related diseases, memory loss, intestinal and prostate problems, impotence, ageing, impeared immune functions, and antibiotic, antineoplasic, antidiarrhoeic and antioxidant properties (Graikou et al., 2011; Morgano et al., 2011). Also, use of bee pollen as food supplement has been proposed to ameliorate various diseases such as bronchitis, dermatitis and allergies (Martín-Muñoz, 2010). However, there are very few studies about using of bee pollen in food and dairy industry.

The aim of this study was to formulate a novel functional fermented milk beverages using bee pollen and selected probiotic strains. Also the effect of bee pollen supplement on antimicrobial, chemical, rheological, sensorial properties and probiotic viability of fermented milk beverages were studied.

\section{Materials and methods}

\section{Materials}

\section{Starter culture and bee pollen}

In the production of fermented milk beverages ABT-1 containing L. acidophilus, Bifidobacterium animalis subsp. lactis and S. thermophilus commercial starter culture (Chr. Hansens's, Hǿrsholm, Denmark) were used. One gram of lyophilized starter culture was added to $100 \mathrm{~mL}$ of sterilized reconstituted skimmed milk containing $0.12 \mathrm{~g} \cdot \mathrm{mL}^{-1}$ dry matter. After milk coagulated $\left(37^{\circ} \mathrm{C}\right)$ at $\mathrm{pH} 4.6$, it was kept at $4{ }^{\circ} \mathrm{C}$ for $24 \mathrm{~h}$. Commercial bee pollen (10\% dry matter, $20 \%$ protein and $31.5 \%$ carbohydrates) were obtained from Ari Dunyasi, Istanbul, Turkey. 


\section{Production of fermented milk beverages}

UHT milks containing $1.5 \%$ fat and $9.0 \%$ nonfat solids divided 6 parts and bee pollens were added in the final concentration so that $2.5 \mathrm{mg} \cdot \mathrm{mL}^{-1}(\mathrm{~B})$, $5 \mathrm{mg} \cdot \mathrm{mL}^{-1}$ (C), $7.5 \mathrm{mg} \cdot \mathrm{mL}^{-1}$ (D), $10 \mathrm{mg} \cdot \mathrm{mL}^{-1}(\mathrm{E})$, and $20 \mathrm{mg} \cdot \mathrm{mL}^{-1}(\mathrm{~F})$ in sterilized bottle. Bee pollen was not added into the control sample (A). After then activated starter culture were added to rate of $3 \%$. The fermentation lasted after ten hours. At the end of the fermentation $\mathrm{pH}$ reached 4.8 and incubation was ended. Samples were put into sterilized glass cups $(500 \mathrm{~mL})$ and stored at $4{ }^{\circ} \mathrm{C}$, until the antimicrobial activity, physico-chemical, rheological, and microbiological analysis were carried out on $1^{\text {st }}$, $7^{\text {th }}, 14^{\text {th }}$ and $21^{\text {st }}$ days. The experiment was carried out twice.

\section{Physico-chemical analyses}

Proteins were determined by the Kjeldahl method, total solids by drying at $105^{\circ} \mathrm{C}$ until constant mass according to the National Standard (TSE, 2003), titratable acidity of the samples was measured by titrating a $10 \mathrm{~mL}$ sample with $0.1 \mathrm{~mol} \cdot \mathrm{L}^{-1}$ $\mathrm{NaOH}$ using phenolphthalein as indicator (Oysun, 2001) and the results were expressed as percentage of lactic acid. $\mathrm{pH}$ value of samples was measured on a Microprocessor $\mathrm{pH} 211$ digital pH-meter (Hanna Instruments, Amorim - Povoa de Varzim, Portugal) standardized with pH 4.00 and 7.00 using standard buffer solutions (Helrich, 1990). The extent of proteolysis was determined by measuring the free amino acid concentration in the filtrates of lactic beverages by the method of Church et al. (1983). $150 \mu \mathrm{L}$ filtrate was mixed with $3 \mathrm{~mL}$ of OPA (o-phthaldialdehyde, Sigma-Aldrich, St. Louis, Missouri, USA) reagent for $10 \mathrm{~s}$, and the resulting absorbance was measured at $340 \mathrm{~nm}$ within $2 \mathrm{~min}$. using spectrophotometer Spekol-1300 (Analytik Jena, Jena, Germany). Results were given as abs at $340 \mathrm{~nm}$.

\section{Measurement of viscosity}

A Brookfield Rotational Rheometer (Model DV-II Pro LV, Brookfield Engineering Laboratories, Middleboro, Massachusetts, USA) with LV-3 cylindrical spindle was used for determination of rheological properties of fermented milk beverages on $2 \mathrm{~m} \cdot \mathrm{s}^{-1}$ at $8{ }^{\circ} \mathrm{C}$ (Demir et al., 2012). Viscosity values of samples were recorded using RHEOCALC
32 Application Software (Brookfield Engineering Laboratories) and all viscosity measurements were expressed in millipascal-seconds.

\section{Antimicrobial activity}

\section{Preparation of pathogen and spoilage \\ microorganisms}

Foodborne pathogens and spoilage microorganisms (Listeria monocytogenes ATCC 7644, Escherichia coli ATCC 8739, Bacillus cereus ATCC 10876, Staphylococcus aureus ATCC 25923, Salmonella typhimurium ATCC 14028, Pseudomonas fluorescens NRRL-B6, Pseudomonas aeruginosa ATCC 9027, Aeromonas hydrophilia B8, Campylobacter jejuni C7) for antibacterial activity were received from the collection Department of Dairy Technology (Ege University, Izmir, Turkey). Test microorganisms were inoculated to Tryptic Soy Broth (Oxoid, Basingstoke, United Kingdom) and incubated at appropriate incubation conditions until the population reached $10^{7}-10^{8} \mathrm{CFU} \cdot \mathrm{mL}^{-1}$.

\section{Determination of antimicrobial activity}

Antimicrobial activity of fermented milk beverag-

Semi-skimmed UHT cow milk

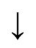

Heat treatment $\left(37^{\circ} \mathrm{C}\right)$

$\downarrow$

Adding of bee pollen (0.25-2 \%)

$\downarrow$

Mixing (gently)

$\downarrow$

Inoculation of probiotic ABT-1 culture

$\downarrow$

Incubation (at $37^{\circ} \mathrm{C}$ until $\mathrm{pH} 4.8$ )

$\downarrow$

Cooling $\left(<10^{\circ} \mathrm{C}\right)$

$\downarrow$

Packed in sterile cups

$\downarrow$

Storage $\left(+4{ }^{\circ} \mathrm{C}\right)$

Figure 1. Flow diagram of laboratory scale production of fermented milk beverages supplemented with bee pollen 
es were determined by the agar disc diffusion method according to Akpinar et al. (2011). All tests were performed in Tryptic Soy Agar (Oxoid).

Suspensions of test bacteria were added containing $25 \mathrm{~mL}$ sterile Tryptic Soy Agar at $44-48$ ${ }^{\circ} \mathrm{C}$, and poured into petri plates $(8 \mathrm{~cm}$ diameter). Plates were left at $37{ }^{\circ} \mathrm{C}$ for $1 \mathrm{~h}$ and the paper discs diffusion was used to detect the antibacterial activity of fermented milk beverages. Then, plates were left appropriate temperature for incubation. After the incubation, inhibition zones formed in the medium were measured in millimeters. Antimicrobial activity was evaluated negative (-) for zone diameters less than $8 \mathrm{~mm}, 8 \mathrm{~mm}$ positive $(+),-10 \mathrm{~mm}$ positive $(++)$, and $11-14 \mathrm{~mm}$ positive $(+++)$ for zone diameters. The experiment was performed in duplicate.

\section{Microbiological analyses}

The colony counts of L. acidophilus, B. lactis, and $S$. thermophilus were enumerated in each sample $(10 \mathrm{~mL})$ following serial dilution in steril peptone water $\left(1 \mathrm{mg} \cdot \mathrm{mL}^{-1}\right)$. Appropriate dilutions were plated in duplicate using the following selective media (Oxoid; Sigma-Aldrich): MRS-sorbitol agar, MRS-nalidixic acid, neomycin sulphate, lithium chloride and paromomycin sulphate (NNLP) agar, M-17 (Merck, Darmstadt, Germany) and incubated anaerobically at $37^{\circ} \mathrm{C}$ for $72 \mathrm{~h}$ and aerobically $37^{\circ} \mathrm{C}$ for $72 \mathrm{~h}$ were used for the enumeration of $\mathrm{L}$. acidophilus, B. lactis and S. thermophilus respectively (Tharmaraj and Shah, 2003).

\section{Sensorial analysis}

The prepared fermented milk beverage samples were analysed for aroma, texture, and general acceptability after $1,7,14$, and 21 days of storage at $4{ }^{\circ} \mathrm{C}$. The acceptability test was carried out with 7 educated panelists familiar with the product. A 9-point hedonic scale was used to evaluate the acceptability of the products including both the number and verbal scores were provided to the panelists. The scores were; like extremely (9), like very much (8), like moderately (7), neither like nor dislike (5), dislike moderately (3), dislike very much (2), and dislike extremely (1). A section for the panelist's comments was present in the evaluation sheet (Bodyfelt et al., 1998; Koksoy and Kilic, 2004).

\section{Statistical analysis}

Statistical analysis of the obtained data was performed by the analysis of variance in SPSSv.10.05 (SPSS, Chicago, Illinois, USA). Means with a significant difference were compared by Duncan's multiple range tests. P-values $<0.05$ were considered statistically significant. All analyses were performed in triplicate.

\section{Results and discussion}

\section{Physico-chemical properties}

The main values for total solids and fat concentration of fermented milk beverages at $1^{\text {st }}$ day of storage are given Table 1 . The main differences among fermented milk beverages resulted from the addition of bee pollen. As expected, the supplemented with pollen of fermented milk beverages resulted in an increase $(\mathrm{P}<0.05)$ of total solids content. This is a consequence of the relatively high concentration of dry matter and protein in pollen. Similar results were obtained by researchers such as Cais-Sokolińska, Pikul et al. (2002), Mahdian and Tehrani (2007), De Souza Oliveria et al. (2009), and Marafon et al. (2011) who studied addition of nutrients to various milk products.

Since pollen usually does not contain fat, no significant differences were observed in fat concentration. However protein values varied significantly, which was significantly affected by the addition of $20 \mathrm{mg} \cdot \mathrm{mL}^{-1}$ pollen $(\mathrm{P}<0.05)$. The OPA-based spectrophotometric assay detects released a-amino groups, which originate from the proteolysis of milk proteins, thus giving a direct measurement of proteolytic activity (Shihata and Shah, 2000). On the contrary of our results, some researchers have suggested that proteolysis exerts two types of effects, an increase in the digestibility and a decrease in firmness or viscosity of the product (Sarkar and Misra, 2010).

Investigation of proteolytic activity levels showed an increase in the proteolytic activity levels of pollen added beverages $(\mathrm{P}<0.05)$. Such findings probably resulted from the relatively high protein concentration of pollen added samples. The variable protein concentration (between $20.0 \%$ and $35.0 \%$ ) of pollen was proposed by many researchers (Morgano et al., 2011; Roldán et al., 2011). Therefore, 
Table 1. Total solids, fat and protein concentration and proteolytic activity of fermented milk beverages supplemented with bee pollen ( $1^{\text {st }}$ day)

\begin{tabular}{ccccc}
\hline Sample & $\begin{array}{c}\text { Total solids } \\
(\%)\end{array}$ & $\begin{array}{c}\text { Fat } \\
(\%)\end{array}$ & $\begin{array}{c}\text { Protein } \\
(\%)\end{array}$ & $\begin{array}{c}\text { Proteolytic activity } \\
\text { (Free amino acids equivalent) }\end{array}$ \\
\hline A & $9.0 \pm 0.10$ & $1.6 \pm 0.1$ & $3.4 \pm 0.10$ & $0.6 \pm 0.28$ \\
B & $9.1 \pm 0.10$ & $1.6 \pm 0.1$ & $3.4 \pm 0.02$ & $0.7 \pm 0.20$ \\
C & $9.2 \pm 0.10$ & $1.5 \pm 0.1$ & $3.4 \pm 0.01$ & $0.8 \pm 0.15$ \\
D & $9.4 \pm 0.10$ & $1.5 \pm 0.1$ & $3.5 \pm 0.01$ & $0.8 \pm 0.30$ \\
E & $9.5 \pm 0.10$ & $1.5 \pm 0.1$ & $3.5 \pm 0.02$ & $0.9 \pm 0.15$ \\
F & $10.1 \pm 0.10$ & $1.4 \pm 0.1$ & $3.6 \pm 0.02$ & $1.5 \pm 0.25$ \\
\hline
\end{tabular}

A: Control sample (without bee pollen)

B: $2.5 \mathrm{mg} \bullet \mathrm{mL}^{-1}$ supplement with bee pollen

C: $5 \mathrm{mg} \bullet \mathrm{mL}^{-1}$ supplement with bee pollen

D: $7.5 \mathrm{mg} \bullet \mathrm{mL}^{-1}$ supplement with bee pollen

E: $10 \mathrm{mg} \bullet \mathrm{mL}^{-1}$ supplement with bee pollen

F: $20 \mathrm{mg} \bullet \mathrm{mL}^{-1}$ supplement with bee pollen

The results are expressed as mean value \pm standard deviation

even a slight increase in protein concentration was achieved depending on the concentration of the pollen added, and this increase had an impact on the proteolytic activities of the samples.

The $\mathrm{pH}$ and acidity values of fermented milk beverages during storage are shown in Table 2. The results of a decrease in $\mathrm{pH}$ with or without bee pollen were the different during storage in all samples. Therefore, pollen supplementation to fermented milk beverages had an influence on the $\mathrm{pH}$ decrease. While $\mathrm{pH}$ values for the samples were ranged between 4.63 and 4.57 at the first day of storage $(\mathrm{P}>0.05)$, at the end of storage were 4.07 and $4.21(\mathrm{P}<0.05)$.

Tamime and Robinson (2007) suggested that the obtainment of fermented milks in this $\mathrm{pH}$ range could result in a better rearrangement and aggregation of casein particles. It is obvious that the values of titratable acidity increased significantly $(\mathrm{P}<0.05)$

Table 2. $\mathrm{pH}$ changes and acidity values of fermented milk supplemented with bee pollen

\begin{tabular}{|c|c|c|c|c|c|c|}
\hline & \multirow{2}{*}{ Sample } & \multicolumn{4}{|c|}{ Storage period $(\mathrm{d})$} & \multirow[b]{2}{*}{ Average } \\
\hline & & 1 & 7 & 14 & 21 & \\
\hline \multirow{6}{*}{$\mathrm{pH}$} & A & $4.57 \pm 0.03^{Z}$ & $4.37 \pm 0.03^{\mathrm{Yab}}$ & $4.30 \pm 0.00^{\mathrm{Ybc}}$ & $4.12 \pm 0.03^{\mathrm{Xab}}$ & $4.3 \pm 0.17$ \\
\hline & B & $4.62 \pm 0.03^{\mathrm{T}}$ & $4.49 \pm 0.01^{z c}$ & $4.39 \pm 0.01^{\mathrm{Yd}}$ & $4.16 \pm 0.04^{\times b c}$ & $4.4 \pm 0.18$ \\
\hline & $\mathrm{C}$ & $4.63 \pm 0.02^{\mathrm{T}}$ & $4.42 \pm 0.03^{\mathrm{Zbc}}$ & $4.33 \pm 0.02^{\mathrm{Yc}_{\mathrm{c}}}$ & $4.07 \pm 0.03^{\mathrm{Xa}}$ & $4.4 \pm 0.21$ \\
\hline & $\mathrm{D}$ & $4.62 \pm 0.03^{\mathrm{T}}$ & $4.43 \pm 0.03^{\mathrm{Zbc}}$ & $4.30 \pm 0.00^{\mathrm{Ybc}}$ & $4.18 \pm 0.02^{\mathrm{Xbc}}$ & $4.4 \pm 0.17$ \\
\hline & E & $4.63 \pm 0.02^{\mathrm{T}}$ & $4.39 \pm 0.00^{\mathrm{Zab}}$ & $4.26 \pm 0.02^{\mathrm{Yab}}$ & $4.21 \pm 0.00^{\mathrm{Xc}}$ & $4.4 \pm 0.17$ \\
\hline & $\mathrm{F}$ & $4.63 \pm 0.02^{\mathrm{T}}$ & $4.34 \pm 0.00^{\mathrm{Za}}$ & $4.25 \pm 0.00^{\mathrm{Ya}}$ & $4.17 \pm 0.03^{\mathrm{Xbc}}$ & $4.4 \pm 0.18$ \\
\hline \multirow{6}{*}{$\begin{array}{c}\text { Acidity } \\
(\%)\end{array}$} & A & $0.7 \pm 0.00^{\mathrm{Xa}}$ & $0.7 \pm 0.00^{\mathrm{Xa}_{\mathrm{a}}}$ & $0.8 \pm 0.01^{\mathrm{Ya}}$ & $1.0 \pm 0.00^{\mathrm{Zb}}$ & $0.8 \pm 0.10$ \\
\hline & B & $0.8 \pm 0.00^{\mathrm{Xab}}$ & $0.8 \pm 0.00^{\mathrm{xb}}$ & $0.8 \pm 0.00^{\text {Yab }}$ & $0.9 \pm 0.01^{\mathrm{Za}}$ & $0.8 \pm 0.08$ \\
\hline & $\mathrm{C}$ & $0.8 \pm 0.01^{\mathrm{Xbc}}$ & $0.8 \pm 0.00^{\mathrm{Xc}}$ & $0.9 \pm 0.02^{\mathrm{Yb}}$ & $0.9 \pm 0.00^{\mathrm{Za}}$ & $0.8 \pm 0.06$ \\
\hline & $\mathrm{D}$ & $0.8 \pm 0.01^{\mathrm{Xbc}}$ & $0.8 \pm 0.00^{\mathrm{Yc}}$ & $0.9 \pm 0.01^{\mathrm{Zb}}$ & $1.0 \pm 0.00^{\mathrm{Tc}}$ & $0.9 \pm 0.09$ \\
\hline & $\mathrm{E}$ & $0.8 \pm 0.00^{\mathrm{xd}}$ & $0.8 \pm 0.00^{\mathrm{Yd}}$ & $0.9 \pm 0.0 \mathrm{l}^{\mathrm{Zb}}$ & $1.0 \pm 0.00^{\mathrm{Tc}}$ & $0.9 \pm 0.08$ \\
\hline & $\mathrm{F}$ & $0.8 \pm 0.02^{\mathrm{Xbc}}$ & $0.9 \pm 0.00^{\mathrm{Ye}}$ & $0.9 \pm 0.01^{\mathrm{Yc}_{\mathrm{c}}}$ & $1.1 \pm 0.00^{\mathrm{Zd}}$ & $0.9 \pm 0.13$ \\
\hline
\end{tabular}

A: Control sample (without bee pollen)

B: $2.5 \mathrm{mg} \cdot \mathrm{mL}^{-1}$ supplement with bee pollen

C: $5 \mathrm{mg} \bullet \mathrm{mL}^{-1}$ supplement with bee pollen

D: $7.5 \mathrm{mg} \bullet \mathrm{mL}^{-1}$ supplement with bee pollen

E: $10 \mathrm{mg} \cdot \mathrm{mL}^{-1}$ supplement with bee pollen

F: $20 \mathrm{mg} \cdot \mathrm{mL}^{-1}$ supplement with bee pollen

$\mathrm{X}, \mathrm{Y}, \mathrm{Z}, \mathrm{T}$ : Values with the same capital letters in the same row for each analysis show significant differences $(\mathrm{P}<0.05)$

$\mathrm{a}, \mathrm{b}, \mathrm{c}, \mathrm{d}$ : Values withy the same lower-case letters in the same column for each analysis show significant differences $(\mathrm{P}<0.05)$

Acidity is expressed as percentage of lactic acid 
Table 3. Viscosity changes of fermented milk beverages supplemented with bee pollen

\begin{tabular}{|c|c|c|c|c|c|c|}
\hline & \multirow[b]{2}{*}{ Sample } & \multicolumn{4}{|c|}{ Storage period $(\mathrm{d})$} & \multirow{2}{*}{ Average } \\
\hline & & 1 & 7 & 14 & 21 & \\
\hline \multirow{6}{*}{$\begin{array}{l}\text { Viscosity } \\
(\mathrm{mPa} \cdot \mathrm{s})\end{array}$} & A & $25.00 \pm 0.70^{\mathrm{Za}}$ & $24.00 \pm 1.41^{\mathrm{YZa}}$ & $22.00 \pm 1.41^{\mathrm{XYa}}$ & $20.00 \pm 0.70^{\mathrm{Xa}}$ & $23.00 \pm 2.20$ \\
\hline & B & $28.00 \pm 1.41^{\mathrm{Za}}$ & $25.00 \pm 1.41^{\mathrm{Ya}}$ & $22.50 \pm 0.70^{\mathrm{XYa}}$ & $21.00 \pm 0.00^{\mathrm{Xa}}$ & $24.12 \pm 2.94$ \\
\hline & $\mathrm{C}$ & $32.50 \pm 0.70^{\mathrm{xb}}$ & $35.00 \pm 1.41^{\mathrm{XYb}}$ & $37.50 \pm 2.12^{\mathrm{Yb}}$ & $37.50 \pm 0.70^{\mathrm{Yb}}$ & $35.62 \pm 2.44$ \\
\hline & $\mathrm{D}$ & $32.50 \pm 3.53^{\mathrm{Xb}}$ & $37.00 \pm 2.82^{\mathrm{XYb}}$ & $40.00 \pm 4.24^{\mathrm{XYb}}$ & $43.50 \pm 3.53^{\mathrm{Yc}}$ & $38.25 \pm 5.09$ \\
\hline & E & $40.50 \pm 0.70^{\mathrm{Xc}}$ & $43.50 \pm 2.12^{\mathrm{XYc}_{\mathrm{c}}}$ & $46.50 \pm 0.70^{\mathrm{YZc}}$ & $48.00 \pm 1.41^{\mathrm{zc}}$ & $44.62 \pm 3.24$ \\
\hline & $\mathrm{F}$ & $44.00 \pm 1.41^{\mathrm{Xc}_{\mathrm{c}}}$ & $46.50 \pm 2.12^{\mathrm{Xc}}$ & $50.00 \pm 1.41^{\mathrm{Xc}}$ & $58.50 \pm 3.53^{\mathrm{Yd}}$ & $49.75 \pm 6.11$ \\
\hline
\end{tabular}

A: Control sample (without bee pollen)

B: $2.5 \mathrm{mg} \cdot \mathrm{mL}^{-1}$ supplement with bee pollen

C: $5 \mathrm{mg} \bullet \mathrm{mL}^{-1}$ supplement with bee pollen

D: $7.5 \mathrm{mg} \bullet \mathrm{mL}^{-1}$ supplement with bee pollen

E: $10 \mathrm{mg} \cdot \mathrm{mL}^{-1}$ supplement with bee pollen

F: $20 \mathrm{mg} \bullet \mathrm{mL}^{-1}$ supplement with bee pollen

$\mathrm{X}, \mathrm{Y}, \mathrm{Z}, \mathrm{T}$ : Values with the same capital letters in the same row for each analysis show significant differences $(\mathrm{P}<0.05)$

$\mathrm{a}, \mathrm{b}, \mathrm{c}, \mathrm{d}$ : Values withy the same lower-case letters in the same column for each analysis show significant differences $(\mathrm{P}<0.05)$

in all fermented milk beverage samples throughout the 21-day storage period. On the first day titratable acidity of samples was 0.73 to 0.79 , at the end of the storage it varied between 0.93 and 1.12 .

\section{Viscosity properties}

Viscosity of all fermented milk beverages with or without bee pollen supplementation are presented in Table 3. The addition of bee pollen resulted in a significantly $(\mathrm{P}<0.05)$ higher viscosity compared with control sample. The increase in apparent viscosity corresponded with the increase of solid concentration.

$20 \mathrm{mg} \cdot \mathrm{mL}^{-1}$ supplementation had the highest apparent viscosity with $58.50 \mathrm{mPa} \cdot \mathrm{s}$ on $21^{\text {st }}$ day of storage. $\mathrm{C}$ sample had the lowest apparent viscosity value and was significantly different from other samples on $21^{\text {th }}$ day of storage $(\mathrm{P}<0.05)$. The storage time of the fermented milk beverages (control and supplemented with bee pollen) influenced significantly their apparent viscosity (Table 3). While the apparent viscosity values of $B$ and $C$ samples decreased, the apparent viscosity values of the other samples increased during storage period $(\mathrm{P}<0.05)$. This also can be attributed to the higher total solids and protein content in the supplemented with bee pollen compared to control sample. High level of solids in the fermented milk increase viscosity of the final product.

\section{Antimicrobial activity}

The antimicrobial activities of control and pollen added samples were seen in Table 4. While no antimicrobial impact was observed against L. monocytogenes, S. aureus, P. fluorescens, P. aeruginosa and $A$. hydrophilia up to $7.5 \mathrm{mg} \cdot \mathrm{mL}^{-1}$ pollen addition, addition between $10 \mathrm{mg} \cdot \mathrm{mL}^{-1}$ to $20 \mathrm{mg} \cdot \mathrm{mL}^{-1}$ resulted in activity. Pollen addition displayed a positive effect only in inhibition rates against bacteria such as $S$. thyphimurium and E. coli.

Probiotic bacteria used for production of fermented milk products are able to exhibit an antimicrobial effect against a great many of bacteria. This effect might change depending not only on the species of probiotic bacteria or test bacteria, but also on the concentration of the probiotic bacteria in the product. This effect results from the mentioned bacteria themselves, or their metabolites (Šušković et al., 2010).

Pollen addition did not exhibit any effect against bacteria such as Bacillus ssp. and C. jejuni. There was no change in the inhibition ratios at the beginning and end of storage period. These results showed that neither culture bacteria nor pollen had antimicrobial activity. Therefore, antimicrobial activity against those bacteria may be improved by increasing the concentration of pollen addition. 
Sarkar and Misra (2010) studied various degree of antagonism in probiotic acidophilus milk against different pathogenic test organisms. Insignificant change in the antibacterial activity of probiotic acidophilus milk (PAM) against $S$. typhimurium $\mathrm{P} 3$ $(6.0-8.5 \mathrm{~mm})$ and E. coli $018(6.0-8.0 \mathrm{~mm})$ were determined during seven days of storage. However, antibacterial activity of PAM against E. coli 03 (7.0 $\mathrm{mm})$ and $S$. dysenteriae $(8.0 \mathrm{~mm})$ remained unaltered throughout storage.

There is a limited research on antimicrobial activity of bee pollen. Erkmen and Ozcan (2008) investigated the antimicrobial activity of pollen extract at concentrations from $0 \%$ to $2.5 \%(\mathrm{v} / \mathrm{v})$ on bacteria (B. cereus, B. subtilis, E. coli, S. typhimu- rium, S. aureus, L. monocytogenes and Yersinia enterocolitica, Enterococcus faecalis), yeasts (Saccharomyces cerevisiae and Candida rugosa), and molds (Aspergillus niger and Rhizopus oryzae). But, these concentrations had no antimicrobial effect on the bacteria and fungi. The results showed that the antimicrobial activity depended on concentration.

Teresinha Carpes et al. (2007) determined antibacterial activity of some pollen extracts (Parana and Alagoas state) obtained with different concentrations of ethanol by disk diffusion assay. While any ethanolic extract of Parana pollen had no effect on S. aureus and B. cereus; rate at 50, 60, 70 and $80 \%$ of Alagoas pollen extract had an effect on S. aureus, rate at 50 and $60 \%$ had an effect on B. ce-

Table 4. Antimicrobial activity of fermented milk beverages supplemented with bee pollen at $1^{\text {st }}$ and $21^{\text {st }}$ days of storage

\begin{tabular}{cccccccc}
\hline & & \multicolumn{7}{c}{ Added pollen rate $\left(\mathrm{mg} \cdot \mathrm{mL}^{-1}\right)$} & \\
\cline { 3 - 7 } Indicator bacteria & Storage $(\mathrm{d})$ & $\mathrm{C}$ & 2.5 & 5.0 & 7.5 & 10 & 20 \\
\hline L. monocytogenes & 1 & - & - & - & - & + & ++ \\
ATCC 7644 & 21 & - & - & - & - & + & ++ \\
E. coli & 1 & + & ++ & ++ & ++ & +++ & +++ \\
ATCC 8739 & 21 & + & ++ & ++ & ++ & +++ & +++ \\
S. aureus & 1 & - & - & - & - & + & ++ \\
ATCC 25923 & 21 & - & - & - & - & + & ++ \\
S. thyphimurium & 1 & + & ++ & ++ & ++ & ++ & +++ \\
ATCC 14028 & 21 & + & ++ & ++ & ++ & ++ & +++ \\
P. fluorescens & 1 & - & - & - & - & + & + \\
NRRL-B6 & 21 & - & - & - & - & + & + \\
P. aeruginosa & 1 & - & - & - & - & + & ++ \\
ATCC 9027 & 21 & - & - & - & - & + & ++ \\
A. hydrophilia & 1 & - & - & - & - & + & ++ \\
B8 & 21 & - & - & - & - & + & ++ \\
C. jejuni & 1 & - & - & - & - & - & - \\
C7 & 21 & - & - & - & - & - & - \\
B. cereus & 1 & - & - & - & - & - & - \\
ATCC 10876 & 21 & - & - & - & - & - & - \\
\hline
\end{tabular}

C: Fermented milk drinks without pollen (control sample)

zone diameter; <8mm: - .8mm: +. 9-10mm: ++. 11-14mm: +++

A: Control sample (without bee pollen)

B: $2.5 \mathrm{mg} \cdot \mathrm{mL}^{-1}$ supplement with bee pollen

C: $5 \mathrm{mg} \bullet \mathrm{mL}^{-1}$ supplement with bee pollen

D: $7.5 \mathrm{mg} \bullet \mathrm{mL}^{-1}$ supplement with bee pollen

E: $10 \mathrm{mg} \bullet \mathrm{mL}^{-1}$ supplement with bee pollen

F: $20 \mathrm{mg} \bullet \mathrm{mL}^{-1}$ supplement with bee pollen 
reus. Furthermore, $P$. auriginosa was inhibited by $\mathrm{Pa}-$ rana pollen extracts rate at 60 and $70 \%$. The results obtained show similarity to the results of aforesaid researchers. Depending on the type of pollen, inhibitions can occur against different species of bacteria and inhibition ratios can also vary.

\section{Viability of probiotic bacteria}

Maintaining the probiotic viability of cultures in food until the end of shelf life is an important criteria to provide probiotic food products. A major challenge associated with the application of probiotic cultures in the fermented dairy products is maintaining of viability. Probiotics, especially bifidobacteria, generally grow poorly in milk compared to the traditional yoghurt bacteria due to the lack of proteolytic and glycolytic activities as well as rela- tively high nutritional demands to some nutrients such as non-protein nitrogen and B-group vitamins (Mohammadi and Mortazavian, 2011).

Many studies stated that several nutrients added into fermented milk products had an impact on the survival of probiotic bacteria; however, in the moment the number of the studies about supplementation of bee polen is still not sufficient to support supplementation.

Table 5 shows the changes in counts (expressed as logarithm of colony-forming units per milliliter) of the L. acidophilus, B. lactis, and S. thermophilus during period storage of fermented milk beverages. In general, the counts of $S$. thermophilus were higher than those of probiotic bacteria, at the beginning and at the end of the $21^{\text {st }}$ day of storage period. This finding is complying with the specifications given by

Table 5. Viability of starter culture bacteria of fermented milk beverages supplemented with bee pollen during storage period

\begin{tabular}{|c|c|c|c|c|c|}
\hline & \multirow{2}{*}{ Sample } & \multicolumn{4}{|c|}{ Storage period (d) } \\
\hline & & 1 & 7 & 14 & 21 \\
\hline \multirow{6}{*}{$\begin{array}{l}\text { L. acidophilus } \\
\left(\log \mathrm{CFU} \cdot \mathrm{mL}^{-1}\right)\end{array}$} & $\mathrm{A}$ & $9.32 \pm 0.00^{\mathrm{Xe}}$ & $9.33 \pm 0.01^{\mathrm{Xd}}$ & $9.40 \pm 0.00^{\mathrm{Yd}}$ & $9.31 \pm 0.01^{\mathrm{Xc}}$ \\
\hline & B & $8.57 \pm 0.04^{\mathrm{Zd}}$ & $7.65 \pm 0.07 \times b$ & $7.97 \pm 0.09^{\mathrm{Yb}}$ & $9.06 \pm 0.02^{\mathrm{Tc}}$ \\
\hline & $\mathrm{C}$ & $7.75 \pm 0.00^{\mathrm{b}}$ & $7.76 \pm 0.02^{c}$ & $8.29 \pm 0.12^{c}$ & $7.99 \pm 0.46^{\mathrm{b}}$ \\
\hline & $\mathrm{D}$ & $7.59 \pm 0.04^{\mathrm{Ya}}$ & $7.57 \pm 0.02^{\mathrm{Yb}}$ & $7.21 \pm 0.14^{\mathrm{Xa}}$ & $7.19 \pm 0.01^{\text {Ха }}$ \\
\hline & $\mathrm{E}$ & $8.58 \pm 0.02^{\mathrm{Zd}}$ & $7.62 \pm 0.04^{\mathrm{Yb}}$ & $7.29 \pm 0.42^{\mathrm{Xa}}$ & $7.20 \pm 0.00^{\mathrm{Xa}}$ \\
\hline & $\mathrm{F}$ & $8.01 \pm 0.09^{z_{c}}$ & $7.45 \pm 0.00^{\text {Ya }}$ & $7.31 \pm 0.14^{\mathrm{Xa}}$ & $7.27 \pm 0.01^{\mathrm{Xa}}$ \\
\hline \multirow{6}{*}{$\begin{array}{l}\text { B. animalis subsp. lactis } \\
\left(\log \mathrm{CFU} \cdot \mathrm{mL}^{-1}\right)\end{array}$} & $\mathrm{A}$ & $8.02 \pm 0.02$ & $7.92 \pm 0.03^{\mathrm{cd}}$ & $8.49 \pm 0.77^{b}$ & $7.87 \pm 0.03^{e}$ \\
\hline & B & $8.04 \pm 0.05^{Y}$ & $8.04 \pm 0.05^{\mathrm{Yd}}$ & $7.00 \pm 0.00^{\mathrm{Xa}}$ & $7.00 \pm 0.00^{X_{c d}}$ \\
\hline & $\mathrm{C}$ & $7.85 \pm 0.21^{Y}$ & $7.25 \pm 0.49^{\mathrm{XYb}}$ & $6.86 \pm 0.12^{\mathrm{Ya}}$ & $6.82 \pm 0.17^{\mathrm{Yc}_{\mathrm{c}}}$ \\
\hline & $\mathrm{D}$ & $8.49 \pm 0.71^{Y}$ & $7.50 \pm 0.02^{\mathrm{Xbc}}$ & $7.11 \pm 0.01^{\mathrm{Xa}}$ & $7.08 \pm 0.02^{\mathrm{Xd}}$ \\
\hline & E & $8.00 \pm 0.00^{z}$ & $7.48 \pm 0.00^{\mathrm{Ybc}}$ & $6.47 \pm 0.02^{\mathrm{Xa}}$ & $6.50 \pm 0.07^{\mathrm{xb}}$ \\
\hline & $\mathrm{F}$ & $8.04 \pm 0.06^{\mathrm{Z}}$ & $6.02 \pm 0.02^{\mathrm{Xa}}$ & $6.30 \pm 0.14^{\mathrm{Ya}}$ & $6.17 \pm 0.03^{\mathrm{XYa}}$ \\
\hline \multirow{6}{*}{$\begin{array}{l}\text { S. thermophilus } \\
\left(\log \mathrm{CFU} \cdot \mathrm{mL}^{-1}\right)\end{array}$} & $\mathrm{A}$ & $10.04 \pm 0.05^{\mathrm{d}}$ & $10.07 \pm 0.03^{c}$ & $10.13 \pm 0.02^{\mathrm{f}}$ & $10.14 \pm 0.02^{\mathrm{f}}$ \\
\hline & B & $9.65 \pm 0.07^{Z c}$ & $9.14 \pm 0.06^{\mathrm{xb}}$ & $9.31 \pm 0.01^{\mathrm{Ye}}$ & $9.40 \pm 0.00^{Y e}$ \\
\hline & $\mathrm{C}$ & $9.24 \pm 0.08^{b}$ & $9.13 \pm 0.02^{b}$ & $9.06 \pm 0.02^{\mathrm{d}}$ & $9.06 \pm 0.09^{d}$ \\
\hline & $\mathrm{D}$ & $9.00 \pm 0.00^{\mathrm{Za}}$ & $8.87 \pm 0.03^{\mathrm{xb}}$ & $8.94 \pm 0.01^{\mathrm{Yc}}$ & $8.94 \pm 0.00^{\mathrm{Yc}}$ \\
\hline & $\mathrm{E}$ & $10.20 \pm 0.00^{Y e}$ & $8.10 \pm 0.70^{\mathrm{Xa}}$ & $8.09 \pm 0.02^{\mathrm{Xa}}$ & $8.06 \pm 0.02^{\mathrm{Xa}}$ \\
\hline & $\mathrm{F}$ & $9.23 \pm 0.00^{\mathrm{Tb}}$ & $9.15 \pm 0.00^{\mathrm{Zb}}$ & $8.63 \pm 0.02^{\mathrm{Yb}}$ & $8.56 \pm 0.00^{\mathrm{xb}}$ \\
\hline
\end{tabular}

A: Control sample (without bee pollen)

B: $2.5 \mathrm{mg} \bullet \mathrm{mL}^{-1}$ supplement with bee pollen

C: $5 \mathrm{mg} \bullet \mathrm{mL}^{-1}$ supplement with bee pollen

D: $7.5 \mathrm{mg} \bullet \mathrm{mL}^{-1}$ supplement with bee pollen

E: $10 \mathrm{mg} \bullet \mathrm{mL}^{-1}$ supplement with bee pollen

F: $20 \mathrm{mg} \bullet \mathrm{mL}^{-1}$ supplement with bee pollen

$\mathrm{X}, \mathrm{Y}, \mathrm{Z}, \mathrm{T}$ : Values with the same capital letters in the same row for each analysis show significant differences $(\mathrm{P}<0.05)$

a,b,c,d: Values withy the same lower-case letters in the same column for each analysis show significant differences $(P<0.05)$ 
the manufacturer for the ABT-type starter culture (Chr. Hansen, 1995). However, the addition of bee pollen had a significant negative affect $(\mathrm{P}<0.05)$ on their survival rates during storage.

It was observed that $L$. acidophilus count had changed between $7.19 \log \mathrm{CFU} \cdot \mathrm{mL}^{-1}$ to $9.40 \mathrm{log}$ $\mathrm{CFU} \cdot \mathrm{mL}^{-1}$ during the storage period. The initial counts of L. acidophilus La-5 were found to be approximately $1 \log$ cycles lower than those of $S$. thermophilus. The addition of pollen had significant effect $(\mathrm{P}<0.05)$ on the survival of $L$. acidophilus La-5 during storage. Lankaputhra and Shah (1995) have reported that L. acidophilus was good at survival in acidic conditions. Pollen supplementation effects on viability of $B$. lactis negatively, especially the lowest survive were obtained $20 \mathrm{mg} \cdot \mathrm{mL}^{-1}$ supplement. Hence, pollen addition might have antimicrobial activity on the viability of B. lactis. Even so, it can be concluded that except for B. lactis, which must be recommended level of above $6 \mathrm{log}$ $\mathrm{cfu} / \mathrm{mL}$, was maintained in all fermented milk samples throughout the whole period of storage.

Moreover, the continued proteolysis could have provided the essential growth factors which contain form of peptides and amino acids, to improve the survival of the probiotics in the product. In Turkish Food Codex requires fermented dairy products should contain lactic acid bacteria of starter culture origin at concentrations of at least $10^{7} \mathrm{cfu} \cdot \mathrm{mL}^{-1}$ (Turkish Food Codex Fermented Milks Regulation, 2009). Even the counts of L. acidophilus and S. thermophilus exceeded largely during the storage period.

Among all lactic acid bacteria, loss of viability was seen in bifidobacteria during storage. However, storage and different treatments are effective on microbiological counts of samples $(P>0.05)$. It was stated that counts of $B$. lactis were the lowest at the $21^{\text {th }}$ day of storage. Similar results were obtained by Yerlikaya et al. (2012).

Table 6 . Sensory properties of fermented milk beverages supplemented with bee pollen

\begin{tabular}{|c|c|c|c|c|c|}
\hline & \multirow{2}{*}{ Sample } & \multicolumn{4}{|c|}{ Storage period $(\mathrm{d})$} \\
\hline & & 1 & 7 & 14 & 21 \\
\hline \multirow{6}{*}{ Aroma } & $\mathrm{A}$ & $6.55 \pm 0.07^{\mathrm{a}}$ & $6.55 \pm 0.21^{\mathrm{d}}$ & $6.50 \pm 0.00$ & $6.55 \pm 0.07 \mathrm{c}$ \\
\hline & $\mathrm{B}$ & $6.45 \pm 0.07^{\mathrm{Yb}}$ & $6.25 \pm 0.00^{\mathrm{xcd}}$ & $6.40 \pm 0.00^{\mathrm{Y}}$ & $6.50 \pm 0.00^{\mathrm{Yab}}$ \\
\hline & $\mathrm{C}$ & $6.40 \pm 0.14^{\mathrm{bc}}$ & $6.62 \pm 0.17^{\mathrm{d}}$ & $6.32 \pm 0.10$ & $6.47 \pm 0.03^{\mathrm{a}}$ \\
\hline & $\mathrm{D}$ & $6.30 \pm 0.14^{\mathrm{Xc}}$ & $6.05 \pm 0.07^{\mathrm{Ybc}}$ & $6.27 \pm 0.24^{\mathrm{x}}$ & $6.45 \pm 0.07^{\mathrm{Xa}}$ \\
\hline & $\mathrm{E}$ & $6.32 \pm 0.17^{\mathrm{Ycd}}$ & $5.82 \pm 0.03^{\mathrm{Xb}}$ & $6.30 \pm 0.21^{\mathrm{Y}}$ & $6.52 \pm 0.17^{\mathrm{Yb}}$ \\
\hline & $\mathrm{F}$ & $6.27 \pm 0.03^{\mathrm{Yd}}$ & $5.17 \pm 0.24^{\mathrm{Xa}}$ & $6.36 \pm 0.14^{\mathrm{x}}$ & $6.42 \pm 0.03^{\mathrm{Xd}}$ \\
\hline \multirow{6}{*}{ Texture } & $\mathrm{A}$ & $7.80 \pm 0.00^{\mathrm{b}}$ & $7.85 \pm 0.07^{\mathrm{a}}$ & $7.80 \pm 0.00^{\mathrm{ab}}$ & $7.85 \pm 0.07^{\mathrm{b}}$ \\
\hline & B & $7.72 \pm 0.03^{b}$ & $8.05 \pm 0.2 \mathrm{l}^{\mathrm{abc}}$ & $7.75 \pm 0.07^{\mathrm{a}}$ & $7.77 \pm 0.03^{b}$ \\
\hline & $\mathrm{C}$ & $7.65 \pm 0.07^{\mathrm{ab}}$ & $7.80 \pm 0.00^{\mathrm{a}}$ & $7.75 \pm 0.07^{\mathrm{a}}$ & $7.80 \pm 0.07^{b}$ \\
\hline & $\mathrm{D}$ & $7.77 \pm 0.03^{b}$ & $8.20 \pm 0.00^{\mathrm{bc}}$ & $7.80 \pm 0.07^{\mathrm{ab}}$ & $7.62 \pm 0.10^{\mathrm{a}}$ \\
\hline & $\mathrm{E}$ & $7.60 \pm 0.00^{\mathrm{Xa}}$ & $8.30 \pm 0.14^{\mathrm{Yc}_{\mathrm{c}}}$ & $7.75 \pm 0.00^{\mathrm{Xa}}$ & $7.75 \pm 0.03^{\mathrm{Xa}}$ \\
\hline & $\mathrm{F}$ & $7.79 \pm 0.15^{\mathrm{Xc}_{\mathrm{c}}}$ & $7.97 \pm 0.03^{\mathrm{Xab}}$ & $7.92 \pm 0.10^{\mathrm{X}_{c}}$ & $8.57 \pm 0.17^{X_{c}}$ \\
\hline \multirow{6}{*}{ General } & $\mathrm{A}$ & $6.87 \pm 0.03^{c}$ & $6.85 \pm 0.07^{c}$ & $6.90 \pm 0.00$ & $7.05 \pm 0.21^{\mathrm{a}}$ \\
\hline & $\mathrm{B}$ & $6.80 \pm 0.03^{\mathrm{XYbc}}$ & $6.50 \pm 0.00^{\mathrm{xbc}}$ & $6.80 \pm 0.14^{\mathrm{XY}}$ & $6.92 \pm 0.24^{\mathrm{Yab}}$ \\
\hline & $\mathrm{C}$ & $6.72 \pm 0.03^{\mathrm{XYab}}$ & $6.50 \pm 0.00^{\mathrm{xbc}}$ & $6.80 \pm 0.14^{\mathrm{XY}}$ & $6.95 \pm 0.21^{\mathrm{Yb}}$ \\
\hline & $\mathrm{D}$ & $6.67 \pm 0.03^{\mathrm{a}}$ & $6.37 \pm 0.17^{b}$ & $6.75 \pm 0.21$ & $6.72 \pm 0.10^{c}$ \\
\hline & $\mathrm{E}$ & $6.62 \pm 0.03^{\mathrm{XYa}}$ & $6.20 \pm 0.07^{\mathrm{Xab}}$ & $6.80 \pm 0.28^{Y}$ & $6.70 \pm 0.14^{\mathrm{Yc}}$ \\
\hline & $\mathrm{F}$ & $6.62 \pm 0.03^{\mathrm{Ya}}$ & $5.95 \pm 0.35^{\mathrm{Xa}}$ & $6.80 \pm 0.28^{Y}$ & $6.60 \pm 0.14^{\mathrm{XYd}}$ \\
\hline
\end{tabular}

A: Control sample (without bee pollen)

B: $2.5 \mathrm{mg} \bullet \mathrm{mL}^{-1}$ supplement with bee pollen

C: $5 \mathrm{mg} \bullet \mathrm{mL}^{-1}$ supplement with bee pollen

D: $7.5 \mathrm{mg} \bullet \mathrm{mL}^{-1}$ supplement with bee pollen

E: $10 \mathrm{mg} \cdot \mathrm{mL}^{-1}$ supplement with bee pollen

F: $20 \mathrm{mg} \bullet \mathrm{mL}^{-1}$ supplement with bee pollen

$\mathrm{X}, \mathrm{Y}, \mathrm{Z}, \mathrm{T}$ : Values with the same capital letters in the same row for each analysis show significant differences $(\mathrm{P}<0.05)$

a,b,c,d: Values withy the same lower-case letters in the same column for each analysis show significant differences $(\mathrm{P}<0.05)$ 


\section{Sensory properties}

Fermented milk beverages supplemented with bee pollen and control sample were arranged in terms of aroma, texture, general acceptance and the results are presented in Table 6. Although aroma is the most important sensory characteristic, the 20 $\mathrm{mg} \cdot \mathrm{mL}^{-1}$ pee pollen supplemented fermented milk beverage had the lowest scores in aroma properties during storage period. Non supplemented control fermented milk had the highest scores in the other bee pollen supplemented beverages $(\mathrm{P}<0.05)$. Storage period had a positive impact on the aroma scores of the products as well $(\mathrm{P}<0.05)$. Late increasing in acidity and low $\mathrm{pH}$ during storage period, could have positive impact on preferability of fermented milk products.

In general, scores of fermented milk beverages had decreased $(\mathrm{P}<0.05)$ with the addition of bee pollen. According to the aroma panel, the highest scores were given by the panelists to the control sample. Bee pollen supplement influenced negatively the taste of fermented milk samples $(\mathrm{P}<0.05)$. Increase in the amount of lactic acid occurring towards the end of storage period had a positive impact on the flavours of the samples and due to the pollen addition; the negative characteristics could be suppressed.

On the contrary, pollen addition had a positive impact on the texture scores of fermented milk products. Texture scores were influenced positively by increasing ratio of pollen addition, especially the sample enriched with $20 \mathrm{mg} \cdot \mathrm{mL}^{-1}$ of pollen had the highest score $(\mathrm{P}<0.05)$. These results were supported with viscosity properties of samples. Yet, the scores of the $21^{\text {th }}$ day of storage were higher compared to the ones of the $1^{\text {st }}$ day. Increasing the ratio of dry matter in fermented milk beverages made a positive impact on the structural and sensorial properties of the products, which was in conformity with the scores of panelists.

The general acceptance was directly proportional to flavour scores. The control sample obtained the highest scores, while fermented milk beverage enriched with $20 \mathrm{mg} \cdot \mathrm{mL}^{-1}$ of pollen obtained the lowest score. Obtained results showed that enrichment of fermented milk beverages with pollen had a negative effect especially on aroma. Such a product could become more desirable with flavour in- gredients or fruit pulps added in order to mask the strange flavour arising from pollen.

\section{Conclusion}

The results of this study showed that enrichment of fermented milk beverages with bee pollen had affected the acidification profile, counts of viable bacteria and rheological properties. The concentration of $5-7.5 \mathrm{mg} \cdot \mathrm{mL}^{-1}$ of pollen was more appropriate than $10-20 \mathrm{mg} \cdot \mathrm{mL}^{-1}$ because of better acceptability and it can be used less pollen at industrial level. Since the added pollen had negative effects on the sensorial properties, addition of flavour ingredients, fruit pulps, adding sweeting agents during product development could be possible. Also, due to the fact that pollen might have an impact on children's allergies, special attention must be paid to production of such products, and this must be declared on the product labels.

\section{Utjecaj dodatka pčelinjeg peluda na antimikrobna, kemijska, reološka $i$ senzorska svojstva te preživaljavanje probiotika fermentiranih mliječnih napitaka}

\section{Sažetak}

U ovom je istraživanju utvrđivan utjecaj dodatka pčelinjeg peluda na antimikrobna, kemijska, reološka i senzorska svojstva te preživljavanje probiotičke kulture $\mathrm{u}$ fermentiranim mliječnim napitcima. Pčelinji pelud je dodan u koncentracijama od 2,5 $\mathrm{mg} \cdot \mathrm{mL}^{-1}$ (B), $5 \mathrm{mg} \cdot \mathrm{mL}^{-1}$ (C), 7,5 $\mathrm{mg} \cdot \mathrm{mL}^{-1}$ (D), $10 \mathrm{mg} \cdot \mathrm{mL}^{-1}$ (E), i $20 \mathrm{mg} \cdot \mathrm{mL}^{-1}$ (F). Kontrolni uzorak (A) nije sadržavao pčelinji pelud. Kontrolni i obogaćeni uzorci mlijeka fermentirani su komercijalnom ABT1 starter kulturom (Chr. Hansen, Hørsholm, Danska) koja sadrži Lactobacillus acidophilus La 5, Bifidobacterium animalis subs. lactis $\mathrm{Bb} 12$, i Streptococcus thermophilus. Dodatkom 7,5 $\mathrm{mg} \cdot \mathrm{mL}^{-1}$ peluda nije utvrđen antimikrobni utjecaj prema L. monocytogenes, S. aureus, $P$. fluorescens, P. aeruginosa i $A$. hydrophilia, dok je dodatak koncentracija između $10 \mathrm{mg} \cdot \mathrm{mL}^{-1} \mathrm{i}$ $20 \mathrm{mg} \cdot \mathrm{mL}^{-1}$ rezultirao inhibitornom aktivnošću samo 
prema bakterijskim vrstama kao što su $S$. thyphimurium i E. coli. Dodatak pčelinjeg peluda pokazao je pozitivan učinak na preživljavanje probiotika i viskoznost, ali nije povoljno utjecao na senzorska svojstva. Daljnjim povećanjem koncentracije dodane peludi nije utvrđena promjena fizikalno-kemijskih svojstava.

\section{Ključne riječi: pčelinji pelud, fermentirano mlijeko, reološka svojstva, antimikrobno djelovanje, senzorska svojstva}

\section{References}

1. Akpinar, A., Yerlikaya, O., Kı1ıç, S. (2011): Antimicrobial activity and antibiotic resistance of Lactobacillus delbrueckii ssp. bulgaricus and Streptococcus thermophilus strains isolated from Turkish homemade yoghurts. African Journal of Microbiology Research 5, 675-682.

2. Bodyfelt, F. W., Drake, M. A., Rankin, S. A. (1998): Developments in dairy foods sensory science and education: From student contests to impact on product quality. International Dairy Journal 18, 729-734. doi: dx.doi.org/10.1016/j.idairyj.2008.03.011

3. Bogdanov, S. (2013). "Pollen: Production, Nutrition and Health: A Review". Bee Product Science, 15 January 2012. (online). (Accessed: 14 March, 2013). (http:// www.bee-hexagon.net/files/file/fileE/Health/PollenBook2Review.pdf)

4. Cais-Sokolińska, D., Pikul, J., Danków, R. (2002): Quality and stability of the natural yogurt produced from milk condensed with whey protein concentrate. Electronic Journal of Polish Agricultural Universities 5, 1-7.

5. Chr. Hansen (1995): Production of fermented milk products with contents of Lactobacillus acidophilus, bifidobacteria and Streptococcus thermophilus (ABT). In: Nu-trish cultures. Hørsholm: Chr. Hansen, 1995, pp. 17-19.

6. Church, F.C., Swaisgood, H.E., Porter, D.H., Catignani, G.L. (1983): Spectrophotometric assay using o-phthaldialdehyde for determination of proteolysis in milk and isolated milk proteins. Journal of Dairy Science 66, 1219-1227. doi: dx.doi.org/10.3168/jds.S0022-0302(83)81926-2

7. Dave, R.I., Shah, N.P. (1998): Ingredient supplementation effects on viability probiotic bacteria in yogurt. Journal of Dairy Science 81, 2804-2816. doi: dx.doi.org/10.3168/jds.S0022-0302(98)75839-4

8. De Souza Oliveria, R.P., Perego, P., Converti, A., De Oliveria, M.N. (2009): The effect of inulin as a prebiotic on the production of probiotic fibre-enriched fermented milk. International Journal of Dairy Technology 62, 195-203. doi: dx.doi.org/10.1111/j.1471-0307.2009.00471.x

9. Demir, C., Kınık, Ö., Yerlikaya, O., Açu, M. (2012): Effects of apple and lemon dietary fibers on some characteristics of low fat kefir. Milchwissenschaft-Milk Science International 67, 406-410.
10. Erkmen, O., Özcan, M.M. (2008): Antimicrobial Effects of Turkish Propolis, Pollen, and Laurel on Spoilage and Pathogenic Food-Related Microorganisms. Journal of Medicinal Food 11, 587-592. doi: dx.doi.org/10.1089/jmf.2007.0038

11. FAO/WHO. (2001): Health and nutritional properties of probiotics in food including powder milk with live lactic acid bacteria. Report of a joint FAO/WHO expert consultation on evaluation of health and nutritional properties of probiotics in food including powder milk with live lactic acid bacteria, Cordoba, Argentina 2001. Rome : Food and Agriculture Organization of the United Nations, World Health Organization, 2001. 34 pp.

12. Graikou, K., Kapeta, S., Aligiannis, N., Sotiroudis, G., Chondrogianni,N., Gonos,E.,Chinou, I. (2011):Chemical analysis of Greek pollen - Antioxidant, antimicrobial and proteasome activation. Chemistry Central Journal 5, 33. doi: dx.doi.org/10.1186/1752-153X-5-33

13. Granato, D., Branco, G.F., Nazzaro, F., Cruz, A.G., Faria, J.A.F. (2010): Functional Foods and Nondairy Probiotic Food Development: Trends, Concepts, and Products. Comprehensive Reviews in Food Science and Food Safety 9, 292-303. doi: dx.doi.org/10.1111/j.1541-4337.2010.00110.x

14. Guldas, M., Irkin, R. (2010): Influence of Spirulina platensis powder on the microflora of yoghurt and acidophilus milk. Mljekarstvo 60 (4), 237-243.

15. Helrich, K. (1990): Official methods of Analysis of the Association of Official Analytical Chemists. Volume 2, Food composition, additives, natural contaminants. $15^{\text {th }}$ ed. Arlington: Association of Official Analytical Chemists, 647 pp. ISBN 0935584420.

16. Kesenkas, H. (2010): Effect of using different probiotic cultures on properties of Torba (strained) yoghurt. Mljekarstvo 60 (1), 19-29.

17. Knorr, D. (1998): Technology aspects related to microorganisms in functional foods. Trends Food Science and Technology 9, 295-306. doi: dx.doi.org/10.1016/S0924-2244(98)00051-X

18. Koksoy, A., Kilic, M. (2004): Use of hydrocolloids in textural stabilization of a yoghurt drink, ayran. Food Hydrocolloids 18, 593-600. doi: dx.doi.org/10.1016/j.foodhyd.2003.10.002

19. Lankaputhra, W. E. V., Shah, N. P. (1995): Survival of Lactobacillus acidophilus and Bifidobacterium spp. in the presence of acid and bile salts. Cultured Dairy Products Journal, 30, 227.

20. Mahdian, E., Tehrani, M.M. (2007): Evaluation the Effect of Milk Total Solids on the Relationship Between Growth and Activity of Starter Cultures and Quality of Concentrated Yoghurt. American-Eurasian Journal of Agriculture and Environmental Science 2, 587-592.

21. Marafon, A.P., Sumi, A., Alcântara, M.R., Tamime, A.Y., De Oliveira, M.N. (2011): Optimization of the rheological properties of probiotic yoghurts supplemented with milk proteins. LWT - Food Science and Technology 44, 511-519. doi: dx.doi.org/10.1016/j.lwt.2010.09.005 
22. Martín-Muñoz, M. F., Bartolome, B., Camiona, M., Bobolea, I., Garcia Ara, M. C., Quirce, S. (2010): Bee pollen: a dangerous food for allergic children. Identification of responsible allergens. Allergologia et Immunopathologia 38, 263-265. doi: dx.doi.org/10.1016/j.aller.2009.12.003

23. Moayednia, N., Ehsani, M.R., Emamdjomeh, Z., Mazaheri, A.F. (2009): Effect of refrigerated storage time on the viability of probiotic bacteria in fermented probiotic milk beverages. International Journal of Dairy Technology 62, 204-208. doi: dx.doi.org/10.1111/j.1471-0307.2009.00473.x

24. Mohammadi, R., Mortazavian, A.M. (2011): Review Article: Technological Aspects of Prebiotics in Probiotic Fermented Milks. Food Reviews International 27, 192-212. doi: dx.doi.org/10.1080/87559129.2010.535235

25. Morgano, M.A., Milani, R.F., Martins, M.C.T., Rodriguez-Amaya, D.B. (2011): Determination of water content in Brazilian honeybee-collected pollen by Karl Fisher titration. Food Control 22, 1604-1608. doi: dx.doi.org/10.1016/j.foodcont.2011.03.016

26. Oysun, G.: Analysis Methods of Milk Products. $3^{\text {rd }}$ ed. Izmir. Ege University Press, 2001. 230 pp. ISBN: 975483-315-X.

27. Roldán, A., Muiswinkel, G.C.J., Lasanta, C., Palacios, V., Caro, I. (2011): Influence of pollen addition on mead elaboration: Physicochemical and sensory characteristics. Food Chemistry 126, 574-582. doi: dx.doi.org/10.1016/j.foodchem.2010.11.045

28. Salva, S., Nuñez, M., Villena, J., Ramón, A., Font, G., Alvarez, S. (2011): Development of a fermented goats'milk containing Lactobacillus rhamnosus: in vivo study of health benefits. Journal of the Science of Food and Agriculture 91, 2355-2362. doi: dx.doi.org/10.1002/jsfa.4467

29. Sarkar, S., Misra, A.K. (2010): Technological and dietetic characteristics of probiotic acidophilus milk. British Food Journal 112, 275-284. doi: dx.doi.org/10.1108/00070701011029147

30. Senok, A.C. (2009): Probiotics in the Arabian Gulf region. Food and Nutrition Research 1, 1-6.

31. Shihata, A., Shah, N.P. (2000): Proteolytic profiles of yogurt and probiotic bacteria. International Dairy Journal 10, 401-408. doi: dx.doi.org/10.1016/S0958-6946(00)00072-8
32. Šušković, J., Kos, B., Beganović, J., Leboš Pavunc, A., Habjanič, K., Matošić, S. (2010): Antimicrobial activity of lactic acid bacteria. Food Technology and Biotechnology 48, 296-307.

33. Tamime, A.Y. (2002): Fermented milks: A historical food with modern applications - A review. European Journal of Clinical Nutrition 56, 2-15. doi: dx.doi.org/10.1038/sj.ejcn.1601657

34. Tamime, A.Y. (2005): Probiotic Dairy Products. $1^{\text {st }}$ ed. Oxford. John Wiley and Sons, 2005. 216 pp. ISBN 1405121246, 9781405121248.

35. Tamime, A.Y., Robinson, R.K. (2007): Yoghurt Science and Technology. 3rd. ed. Cambridge, Woodhead Publishing, 791 pp. ISBN: 13-978-0849317859.

36. Teresinha Carpes, S., Begnini, R., De Alencar, S.M., Masson, M.L. (2007): Study of preparations of bee pollen extracts, antioxidant and antimicrobial activity. Ciência e Agrotechnologia 31, 1818-1825. doi: dx.doi.org/10.1590/S1413-70542007000600032

37. Tharmaraj, N., Shah, N.P. (2003): Selective Enumeration of Lactobacillus delbrueckii subsp. delbrueckii subsp. bulgaricus, Streptococcus thermophilus, Lactobacillus acidophilus, Bifidobacteria, Lactobacillus casei, Lactobacillus rhamnosus and Propionibacteria. Journal of Dairy Science 86, 2288-2296. doi: dx.doi.org/10.3168/jds.S0022-0302(03)73821-1

38. TSE, TS 3810. (2003): Standard of Ayran. Ankara: Turkish Institute of Standards, 9 pp.

39. Turkish Food Codex Fermented Milks Regulation. (2009/25). Ankara: Republic of Turkey Ministry of Agriculture and Rural Affairs, General Directorate of Protection and Control, 2009. 8 pp.

40. Yerlikaya, O., Akpınar, A., Torunoglu, A., Kınık, O., Akbulut, N., Uysal, H. (2012). Effect of some prebiotic combination on viability of probiotic bacteria in reconstituted whey and milk beverages. AgroFood Industry HiTech, Monographic Supplement Series 23, 27-29. 